Ethiopian Journal of Environmental Studies \& Management 7(3): 310 - 318, 2014.

ISSN:1998-0507

doi: http://dx.doi.org/10.4314/ejesm.v7i3.11

Submitted: February 11, 2014

Accepted: May 2, 2014

\title{
PERCEPTIONS OF CLIMATE CHANGE AND ADAPTATION TO MICROCLIMATE CHANGE AND VARIABILITY AMONG SMALLHOLDER FARMERS IN MHAKWE COMMUNAL AREA, MANICALAND PROVINCE, ZIMBABWE
}

\author{
RUSINGA, 0., ${ }^{1}$ CHAPUNGU, L., ${ }^{1}$ MOYO, P. ${ }^{1}$ AND STIGTER, K. ${ }^{2}$ \\ ${ }^{1}$ Department of Physics, Geography and Environmental Science, Great Zimbabwe University, Box 1235, \\ Masvingo, Zimbabwe \\ ${ }^{2}$ Agromet Vision (Africa and Asia), Groenestraat 13, 5314AJ, Bruchem, Netherlands
}

\begin{abstract}
Climate change and the related increasing variability are real phenomena in sub-Saharan Africa. They are exacerbating climatic risks associated with small-scale agriculture in tropical regions. This study seeks to assess smallholder farmers' perceptions of climate change and also their adaptive strategies at the microscale in Mhakwe Communal Area in Zimbabwe. A mixed method research design was employed to carry out the study. The design was a triangulation of quantitative and qualitative data collection methods. A sample of 43 smallholder farmers was purposively selected because the population of smallholder farmers was unknown. The study noted that government agencies and non-governmental organisations were providing information about climate change and variability to smallholder farmers. Farmers practiced a number of adaptation strategies such as timing in planting, zero tillage, mulching, agroforestry and gardening. The study recommended that external agencies should focus on strengthening existing adaptive strategies. There is also need to scale-up programmes on capacity building with regards to dissemination of analysed weather and climate data.
\end{abstract}

Key Words: Climate change; Adaptation; Agriculture; Smallholder farmers, Vulnerability

\section{Introduction}

Climate change and the related increasing variability are exacerbating risks associated with agriculture at local, regional and planetary scales in tropical regions (Tubiello et al., 2008). The situation is complex in almost all parts of subSaharan Africa where agriculture continues to be the major economic activity at both national and household levels. According to Nhemachena and Hassan (2011), agricultural production remains the main source of livelihood for rural communities, provides employment to more than $60 \%$ of the population and contributes about $30 \%$ of gross domestic product. In addition, the vulnerability of the agricultural sector in subSaharan Africa to consequences of climate change is perceived to be higher than of any other region in the world because of its overdependence on rainfall (Yanda, 2010). In drier parts of Southern Africa, the coefficient of variation in annual rainfall is between $20 \%$ and $40 \%$ while the variation in yield is from less than $15 \%$ to $60 \%$ with high implications for food security (Lumsden and Schulze, 2007 cited in Nanja, 2010). Agricultural production in subSaharan Africa is strongly influenced by variations in the annual cycle of precipitation. These variations are caused by the annually differing movements of the Inter Tropical Convergence Zone and the El Niño-Southern Oscillation (ENSO) dynamics (Joly and Voldoire, 2009 cited in Stigter and Ofori, 2013a). Climate change and the related increasing variability are discussed together in this study, but not used interchangeably, recognising that climate change also manifests itself as increasing variability and more (and possibly more severe) extreme events (Schipper, 2004; Stigter and Ofori, 2013a), without forgetting increasing temperatures as a prime source of trouble (Stigter and Ofori, 2013b). Climate change is defined as any change in climate over time, whether due to natural variability or as a result of human activity (Intergovernmental Panel on Climate Change [IPCC], 2001). Climate variability refers to variations in the mean state and other statistics

*Corresponding Author: Rusinga, O.

Email: orusinga@gmail.com 
(such as standard deviations, the occurrence of extremes, etc.) of the climate on all temporal and spatial scales beyond that of individual weather events (IPCC, 2001).

It had been noted that climate change and its related variability are real phenomena in Zimbabwe (Makarau, 1999; Unganai, 1996). However, there is paucity of information on how Zimbabwean smallholder farmers' perceptions of climate change might influence their choices of adaptive strategies. A study of this nature is necessary because it enables an assessment of the relationship between changes in ecological conditions and adaptive strategies of smallholder farmers in microenvironments. This contributes to the understanding of adaptive capacities of smallholder farmers to climate change in Zimbabwe. Adaptation to climate change also is intertwined with adjustment in human systems. Therefore, adaptive strategies are an integral element of development in that they provide societies with the ability to cope not only with climate change but also perturbations in social, economic and political variables (Pelling, 2003 cited in Schipper, 2004).

In this study, adaptation refers to adjustments in ecological, social or economic systems in response to actual or expected climatic stimuli and their effects or impacts (IPCC, 2001). Schipper (2004) asserts that the IPCC's definition of adaptation is important because it includes both climate change and variability. Adaptive capacity is the potential or ability of a region or community to adjust to climate change, including climate variability and extremes, to moderate potential damages, to take advantage of opportunities or to cope with the consequences (IPCC, 2001).

This study assesses smallholder farmers' perceptions of climate change and also their adaptive strategies at the micro-scale. It adopts a holistic approach as this enhanced the examination of the interaction between natural and human systems in adaptation to climate change among smallholder farmers. Therefore, this study is guided by the following research questions:

- What ecological changes smallholder farmers intuitively observed to interpret climate change and variability in their local area?

- In what ways do smallholder farmers perceive the impacts of climate change and variability?

- To what extent, do perceptions of smallholder farmers influence their adaptive strategies to climate change and variability?

\section{Conceptual Framework}

The conceptual framework is based on an interdisciplinary approach. The study adopts an interdisciplinary approach because the focus is on the interaction between natural and human systems in adaptation to climate change in microenvironments. Nhemachena and Hassan (2011) argue that adaptation to climate generally involves changes in agricultural management practices in response to changes in climate conditions. Indigenously developed farming systems have been adapted to local natural environmental conditions and their viability mostly depends on manipulation of microclimate conditions. The sustainability of these farming systems depends on the ability of farmers to adapt their strategies to the risks related to weather and climate. The ability to adapt is enhanced by exposure to climate related information whether acquired from records or acquainted by interacting with the natural environment. A Farmer First approach was adapted for this study as the basis of the conceptual analysis of smallholder farmers' perceptions and responses to climate change and variability. The rationale of adapting this approach is that farmers have always been adapting their farming methods to changes in weather and climate.

Rural responses to climate change would be sustainable when farmers' knowledge, values and priorities are recognised. Stigter and Winarto (2012a) argue that while science-based approaches are essentially important to enhance society's capability to understand, anticipate and cope with the impacts of climate in order to improve human welfare and the environment, it is also equally important to listen to concerned farmers to better understand their vulnerabilities and needs the way they see them. A Farmer First approach is important because "for farmers, what 
counts is fitting available resources to changing circumstances well enough to make it through the season" (Scoones and Thompson, 2009: 20). The focus on smallholder farmers' perceptions of climate change and variability in this study underlined the intuitive and experiential bases of indigenous knowledge production systems among smallholder communal farmers of Zimbabwe. Apart from weather and climate data, farmers also rely on local ecological conditions to interpret climate change and variability.

\section{Study Area}

Mhakwe Communal Area (Figure 1) is found in Chimanimani District located in the southeastern part of Zimbabwe and is about $150 \mathrm{~km}$ from the City of Mutare. The area is located in agro-ecological region two. According to Chimhowu et al. (2010), region two receives mean annual rainfall of between $700-1000 \mathrm{~mm}$ and the temperatures are cool, $25^{\circ} \mathrm{C}-28^{\circ} \mathrm{C}$. Annual rainfall regimes permit summer season crop cultivation but the area is vulnerable to inter- and intra-seasonal rainfall variability. The physical terrain is characterized by rugged mountains and deep valleys dissected by rivers and streams. Mhakwe Communal Area is in the Nyanyadzi sub-catchment Area. The major rivers supplying water in the area throughout the year are Mhakwe, Shekani and Matanho. The physical landscape appears to be the major influence of human settlements since most people live on low lying areas. Subsistence agriculture is the major economic activity in this area. Crops grown include maize, sorghum, millet, beans and sunflowers, among others.

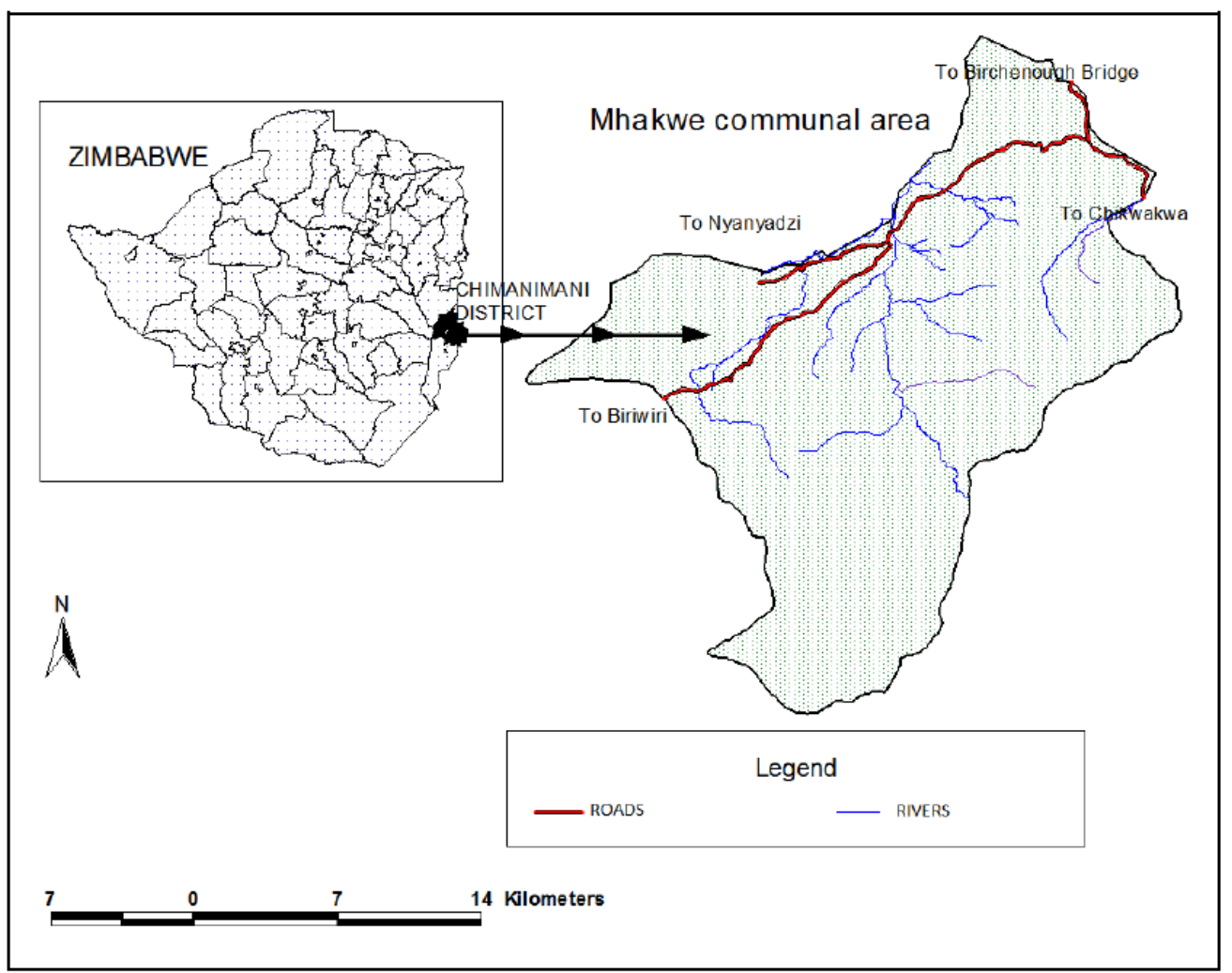

Figure 1 Map showing Zimbabwe, Chimanimani District and Mhakwe Communal Area

\section{Methodology}

A mixed method research design involving collecting, analysing, and mixing both quantitative and qualitative data was employed in the present study (Creswell and Clark, 2011). The design consisted of the triangulation of quantitative and qualitative data collection methods. A sample of 43 smallholder farmers was purposively selected. Purposive selection of participants helped to identify farmers who were knowledgeable about the local biophysical conditions. It involved snowballing, that is 
recruited participating farmers were asked to assist for identifying other farmers in the area who had extensive knowledge about the local biophysical conditions. Therefore, conclusions made in data analysis only refer to the participating farmers.

Forty three questionnaires were distributed to sampled smallholder farmers aged 30 years and above. Questionnaires were used to collect background data, types of crops grown and climate change and climate variability information. Twelve semi-structured interviews were also conducted with some of the participating farmers to understand their farming activities. Six observations were carried out in fields and gardens of farmers we created good rapport with. The main idea of carrying out observations was to have a first visual impression of farmers' activities. They also involved photographing.

\section{Results and Discussion Background Data}

The demographic data of smallholder farmers who responded to questionnaires show that $70 \%$ of respondents were male and $30 \%$ female. Table 1 presents age distribution of respondent farmers to questionnaires. The presentation shows that the highest percentage of respondents $(33 \%)$ were above 65 years, $30 \%$ between $30-45$ years, $20 \%$ were between $46-55$ years and $17 \%$ in $56-55$ years age group.

Table 1 Age Distribution of Respondents

\begin{tabular}{cc}
\hline Age range (in years) & Percentage (\%) \\
\hline $30-45$ & 30 \\
$46-55$ & 20 \\
$56-65$ & 17 \\
$>65$ & 33 \\
\hline Total & 100 \\
\hline $\mathrm{N}=43$ &
\end{tabular}

Sources and Nature of Information about Climate Change

Smallholder farmers reported several sources of information about climate change. Virtually, all respondents mentioned The Department of Agriculture, Research and Extension (AREX) as their main source of climate change and variability information. The media were also important sources of climate-related information, particularly weather forecasts. Figure 2 showed that $70 \%$ of the respondents received information from the radio, $21 \%$ from television, $2 \%$ from newspapers and $7 \%$ other types of media.

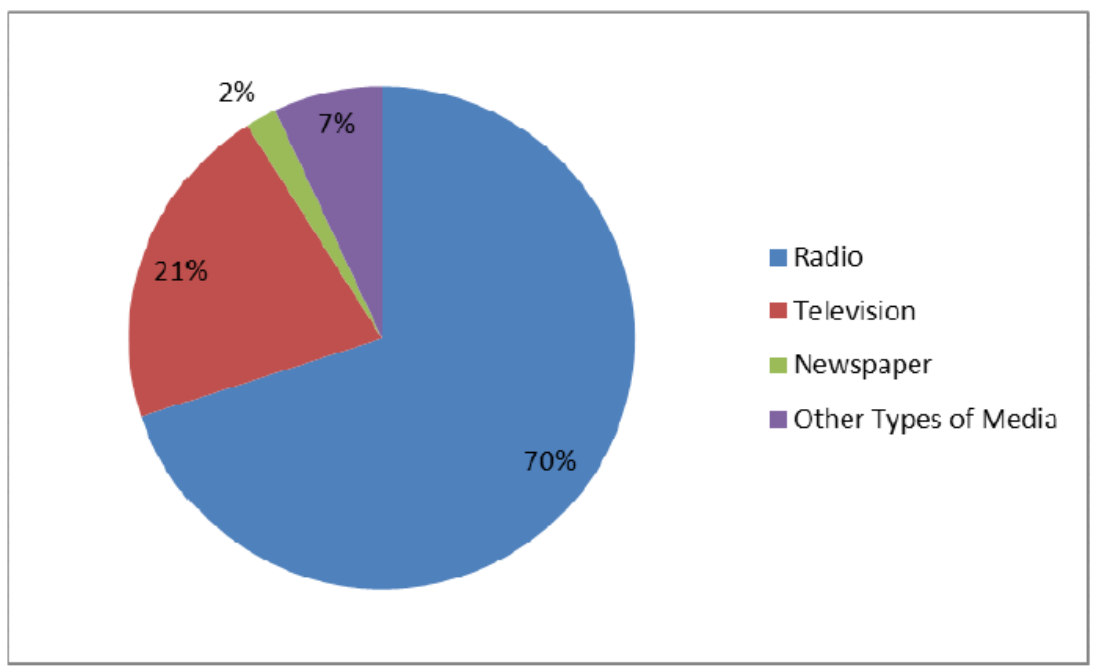

Figure 2 Types of media which farmers received climate-related information

Besides the media, participating farmers revealed that the Environmental Management Agency and Non-governmental Organisations (NGOs), namely, CARITAS and Tsuro DzeChimanimani also provided information about the impacts of climate change. These agencies provided information specifically oriented to response to climate change. These agencies provided information about adaptive strategies, namely, evidence and manipulation of 
seasonal rainfall variability; planting of drought resistant crops; conservation farming methods (for example: zero tillage, mulching, use of manure etc.); early planting and irrigation. According to research findings, no agency directly provided farmers with statistics of climate variables.

It also had been noted that farmers shared information about climate change and variability among themselves. However, they tended to value external sources most. This perhaps was because information of their experiments was shared informally. Mutimba (2003) also noted that farmers do not conduct special meetings for launching the trials nor to publicise the results. However, it is important to encourage farmers to share information about changes they observe themselves as this may assist them in organizing better in other matters of common interest (Stigter and Winarto, 2012b). We observed that external agencies especially Non-governmental Organisations offered incentives, such as maize seeds, which encouraged smallholder farmers to try the demonstrated adaptive strategies.

Micro-environmental Indicators and Farmers' Perceptions of Climate Change and its Related Climate Variability

African smallholder farmers also rely on micro-environmental indicators to study rainfall patterns and their variability due to lack of sophisticated and reliable tools to measure weather conditions. However, with some notable exceptions, summarized in Stigter (1994) and more recently in Stigter (2010), indigenous knowledge systems of local farmers about their micro-environments either have been largely ignored or reproduced without much recognition of local farmers' understanding of their microenvironmental indicators.

Agroecological Conditions and Climate Change

Farmers indicated that they observed agroecological changes in their microenvironments which helped them to interpret changes in climate and also its variability. These observed agroecological changes were related to the study of seasonal rainfall patterns. They acted as reminders or sign posts for timing of land preparation for planting. During interviews, participating farmers highlighted a number of agroecological changes they observed.
Firstly, growth of new tree leaves, especially by early October. Farmers perceived this as heralding the beginning of the summer season. Farmers reported that the growth of new tree leaves usually begins at the end of September. According to them, the interval between growth of new tree leaves and first rains increased. Farmers in Africa are always suffering from "false" starts of the rainy season, but those earlier insufficient rains are very likely sufficient for new leaves to start growing. Farmers now perceived that first rains are coming later than traditionally was the case.

Secondly, ripening of certain types of domestic and wild fruits normally coincided with the onset of the summer season. Examples of wild fruits given by respondents were Monkey orange (Strychnos innocua) and Sour plum (Ximenia americana). Participating farmers perceived that temperatures are increasing because some exotic fruits are now ripening earlier as before.

Thirdly, temperature changes are used to determine timing of seasons. Too hot and cold indicate the beginning and end of the summer season, respectively.

Fourthly, movement of certain types of birds such as southern Ground-hornbill (Bucorvus leadbeateri), Black swift (Apus barbatus), types of stock bird species (Goliath heron [Ardea goliath], Yellow-billed egret [Egretta intermedia], Great white egret [Egretta alba]) and quelea (quelea quelea). These birds increase in population in the area during the summer season. They migrate into the area from midOctober to end of December. In a study of migratory birds in Southern Africa, (Jones et al. 1999) noted that the timing and distribution of rainfall and the growth of annual grasses are the main determinants of the quelea birds' movements. Farmers reported that there was an overall decrease in populations of those birds. They also highlighted that the decrease in population was not related to killing or death but these birds were no longer coming in numbers as they used to do during the summer season. They interpreted this as that the changes in the onset of the rainy seasons might be the main reason.

Fifthly, farmers also interpreted birds' sounds to study rainfall patterns. Farmers reported that rain used to fall within weeks when they heard 
the sound of Ground-hornbill (Bucorvus leadbeateri). Mapara (2009) noted that the Manyika in Chief Tangwena's area, Nyanga District, Zimbabwe also believed in bird sounds. These Manyika reported that they could foretell whether rains were going to fall in the next hour or two if they heard the sound of a rain bird known in local vernacular as dzvotsvotsvo. During interviews, farmers highlighted that they now only sporadically heard the sounds of birds associated with rain, like the Ground-hornbill (Bucorvus leadbeateri). Farmers perceived that climate is changing because those birds' traditional movement patterns and habits were well defined and closely related to seasonal changes in summer seasons.

\section{Adaptive Strategies}

To adapt to climate change, Frank and Buckley (2012) suggested that smallholder producers will need new and improved technologies, skills and knowledge, or in many cases, to be linked to existing technologies which are currently inaccessible to them. These may include improved water management using rainwater harvesting or soil stabilisation techniques; soil conservation and erosion control through terracing and agroforestry (Stigter, 2010). It may be argued that listening to concerned farmers to better understand their vulnerabilities and needs the way they see them is also important (Stigter and Winarto, 2012a). Adaptation strategies must also make use of indigenous knowledge embedded in African agricultural systems in order to improve protection of indigenous crop gene banks. Adaptation also implies ways in which local individuals, households and communities have changed their mix of productive activities and modified their community rules and institutions in response to vulnerabilities in order to meet their livelihood needs (Schipper, 2004) [see Table 2]. In this section, we present adaptive strategies being practiced by participating farmers.

Table 2 Types of Adaptation to Climate Change Table 2 Types of Adaptation to Climate Change

\begin{tabular}{|c|c|c|}
\hline Typology & Main Descriptive Term & Additional/Alternative Terms \\
\hline \multirow[t]{2}{*}{ Purposefulness } & Planned & $\begin{array}{l}\text { Public, purposeful, intentional, policy, active or } \\
\text { strategic. }\end{array}$ \\
\hline & Autonomous & $\begin{array}{l}\text { Private, spontaneous, automatic, passive, natural, } \\
\text { incidental }\end{array}$ \\
\hline \multirow[t]{2}{*}{ Timing } & Reactive & Responsive or ex post \\
\hline & Anticipatory & Proactive or ex ante \\
\hline \multirow[t]{2}{*}{ Duration } & Strategic & Long-term or cumulative \\
\hline & Tactical & Short-term, instantaneous, contingency or routine. \\
\hline \multirow[t]{2}{*}{ Location } & Localised & National \\
\hline & Wide-spread & International \\
\hline
\end{tabular}

Adapted from Schipper (2004)

\section{Timing of Planting}

The study noted that $61 \%$ of respondents kept dates of the onset of summer rainfall while $39 \%$ did not. Of those who kept dates, 39\% recorded in a book while $61 \%$ kept no documented records. About $96 \%$ reported that keeping dates improved their decisions in timing of planting while $4 \%$ mentioned that it was not helpful. Respondents virtually acknowledged that climate is changing. Inter-seasonal variability had been noted. Farmers pointed out that the rainy season used to start in mid-October but it has since changed. It is now becoming a norm that the rainy season starts by late November and in other seasons even by late-December. Inter-seasonal variability was now affecting timing of crop planting, especially of maize varieties. Farmers reported that they were now planting maize varieties in December, when the frequencies of rain-days increased. This showed that farmers took seed varieties' moisture requirements into account for germination when deciding on time of planting. Seed varieties (such as sorghum, millet) which can stay dormant in the soil are sown earlier.

\section{Mixed and Staggered Cropping}

Mixed cropping was one of the adaptive strategies practiced in the area. All participating farmers reported that they planted different crops in one field at the one time. The common mixture 
was maize, groundnuts, round beans, cowpeas and pumpkin or cucumber. Maize, the main crop, was planted in rows and a legume crop (for example, groundnuts, round beans) was planted between rows of maize. Pumpkin and/or cucumber were planted haphazardly. Studies have shown that mixed cropping is important in determining the performance of agroecosystems as it enables the assembling of functional biodiversity and promoting synergies which enhance farm processes such as activation of soil biology, recycling of nutrients, enhancement of biological pest suppression, better use of space, light, moisture and greater yield stability (Stigter, 2010). There is huge potential for mixed cropping as an adaptive strategy. It exploits the full range of micro-environments, which differ in soil, water, temperature, altitude, slope, and fertility within a field or region (Stigter, 2010).

The majority of farmers $(81 \%)$ practiced staggered cropping in time, while 19\% reported that they sowed seeds only once. Some of the factors which influenced such staggered cropping were highlighted. These include duration of maturity of a crop variety; resistance of seeds to moisture stress and planting requirements of a crop, that is whether wet or dry planting.

Farmers who did not practice staggered cropping mentioned other factors independent of seasonal rainfall variability. Their choices of planting once the season starts were either constrained by size of the plot or enhanced by access to the government initiated and donor funded irrigation project in the area.

\section{Zero tillage and mulching}

Participants in interviews revealed that zero tillage and mulching were introduced recently by NGOs as part of conservation farming. The strategies were at an elementary stage of implementation during the time of the study. It had been observed that farmers applied the strategies on portions of their plots. They dig holes in which they sow seeds and they mulch between both rows and holes. Among the respondent farmers, $84 \%$ practised zero tillage and $16 \%$ did not. The receptivity of the strategy among farmers was high.

Respondents of questionnaires were asked to list the benefits of zero tillage and mulching they identified in order to qualify the receptivity of these strategies. Several benefits were highlighted. The common ones were conservation of soil moisture, suppression of weed growth, low costs of land preparation, increment in microbial activities, reduction in leaching of nutrients, reduction in soil compaction, prevention of soil erosion, improvements in crop yields and maintenance of soil structure.

Mulching had mixed effects on plant growth and crop yield quality depending on the type of organic material used. Studies have shown that mulching has some positive effects such as increases in organic matter content and available nutrients (phosphorus and potassium) in the soil. It reduces large fluctuation in soil temperature and improves the porosity and water holding capacity of the soil (Sinkevičiene et al., 2009).

\section{Agroforestry and Gardening}

It had been observed that some farmers in the area were practising agroforestry. Agroforestry was haphazard and heavily concentrated along rivers where there was reliable supply of water for irrigation. Chitakira and Torquebiau (2010) argue that agroforestry is not new in Zimbabwe. Rao et al., 2007) assert that agroforestry brings about favourable changes in the microclimatic conditions by influencing radiation flux, air temperature, wind speed, saturation deficit of understory crops, all of which will have a significant impact on modifying the rate and duration of photosynthesis and subsequent plant growth, transpiration, and soil water use. Recently, Stigter et al. (2011) reviewed microclimate management and manipulation in applied agroforestry.

Farmers divert water from rivers by digging canals to irrigate vegetables and trees. Common exotic fruits grown include mango, paw paw, lemon, orange and banana. Sugar cane, cassava and medicinal plants were also grown. Agroforestry is practised simultaneously with gardening.

\section{Conclusion}

The persuasive evidence that smallholder farmers in Mhakwe Communal Area are practising a wide array of adaptive strategies to climate change and variability reveals the reality on the ground. All participating farmers perceive that climate is changing. Farmers are adapting to changes in local conditions heavily relying on locally available resources. Technological 
transfer without comprehensive knowledge about local indicators might reproduce the problems and complicates the situation. Although these farmers noted several benefits of mulching, NGOs were packaging the strategy in a way that might be reproducing mono-cropping and may lead to loss of wild vegetables. As a choice, mono-cropping is not popular among communal smallholder farmers in Zimbabwe. The sustainability of mono-cropping is not easily recognised among resource poor farmers.

\section{Recommendations}

The study offered the following recommendations:

External agents should put much focus on strengthening existing adaptive strategies in order to improve adaptive capacities of farmers.

There is also need to scale-up programmes on capacity building with regards to measuring, analysing and interpreting, quantitatively and qualitatively, weather/climate data and phenomena, particularly in relation to daily rainfall distribution and its agroecological consequences.

\section{References}

Chimhowu, A., Manjengwa, J. and Feresu, S. (2010). Moving Forward in Zimbabwe: Reducing Poverty and Promoting Growth. Harare: Institute of Environmental Studies.

Chitakira, M. and Torquebiau, E. (2010). Barriers and coping mechanisms relating to agroforestry adoption by smallholder farmers in Zimbabwe. The Journal of Agricultural Education and Extension, 16(2): 147-160.

Creswell, J.W. and Clark, V.L.P. (2011). Designing and Conducting Mixed Methods Research. $2^{\text {nd }}$ ed. London: SAGE Publications, Inc.

Frank, J. and Buckley, C.P. (2012). Small-scale Farmers and Climate Change: How can Farmer Organisations and Fairtrade Build the Adaptive Capacity of Smallholders? London: International Institute for Environment and Development.

IPPC. (2001). Climate Change 2001: The Scientific Basis. Cambridge, United Kingdom: Cambridge University Press.
Jones, P.J., Cheke, R.A., Mundy, P.J., Dallimer, M. and Venn, J.F. (1999). Quelea populations and forecasting in Southern Africa. Workshop on Research Priorities for Migrant Pests of Agriculture in Southern Africa, Plant Protection Research Institute, Pretoria, South Africa, 24-26 March 1999.

Makarau, A. (1999). Zimbabwe's climate: past, present and future. In E. Manzungu, A. Senzanje and P. van der Zaag (Eds.), Water for Agriculture in Zimbabwe. Policy and Management Options for the Smallholder Sector. Harare: University of Zimbabwe Publications.

Mapara, J. (2009). Indigenous knowledge systems in Zimbabwe: Juxtaposing postcolonial theory. Journal of Pan African Studies, 3(1): 139-155.

Mutimba, J. (2003). Towards an understanding of technology needs of smallholder farmers. In A Bolding, J. Mutimba and P. van der Zaag (Eds.), Interventions in Smallholder Agriculture: Implications for Extension in Zimbabwe. Harare: University of Zimbabwe Publications.

Nanja, D.H. (2010). Dissemination of Climate Information to Small-Holder Farmers: A Case Study for Mujika Area, Zambia. Unpublished PhD, University of Free State, South Africa.

Nhemachena, C. and Hassan, R.M. (2011). Micro-level analysis of farmers adaptation to climate change in Southern Africa. International Food Policy Research Institute Discussion Paper 00714.

Rao, K.P.C., Verchot, L.V. and Laarman, J. (2007). Adaptation to climate change through sustainable management and development of agroforestry systems. SAT eJournal, 4(1): 1-30.

Schipper, E.L.F. (2004). Exploring Adaptation to Climate Change. A Development Perspective. Unpublished $\mathrm{PhD}$ Thesis, University of East Anglia, United Kingdom.

Scoones, I. and Thompson, J. (2009). Introduction. In I. Scoones and J. Thompson (Eds.), Beyond Farmer First. Rural People's Knowledge, Agricultural Research and Extension Practice. 
Warwickshire, United Kingdom, Practical Action Publishing.

Sinkevičienè, A., Jodaugienè, D., Pupalienè, R. and Urboniene, M. (2009). The influence of organic mulches on soil properties and crop yield. Agronomy Research, 7(Special issue I): 485-491.

Stigter, C.J. (1994). Management and manipulation of microclimate. J. F. Griffiths (Ed.), Handbook of Agricultural Meteorology. Oxford: Oxford University Press.

Stigter, K. (Ed.) (2010). Applied Agrometeorology. Berlin/Heidelberg: Springer.

Stigter, K., Ofori, E., Kyei-Baffour N. and Walker, S. (2011). Microclimate management and manipulation in applied agroforestry. The Overstory 240, Agroforestry e-journal, October 16th, overstory@agroforestry.net.

Stigter, C.J. and Winarto, Y.T. (2012a). What climate change means for farmers in Asia. Earthzine, Agriculture, Articles, Climate Consensus. Posted 17 April http://www.earthzine.org/2012/04/04/whatclimate-change-means-for-farmers-in-asia.

Stigter, C.J. and Winarto, Y.T. (2012b). Considerations of Climate and Society in Asia: Farmers in Indonesia. Earthzine, Agriculture, Articles, Climate Consensus. Posted 6 April: http://www.earthzine.org/2012/04/04/whatclimate-change-means-for-farmers-in-asia.

Stigter, C.J. and Ofori, E. (2013a) Climate extremes and society's responses, including mitigation attempts as part of preparedness of African farmers. African Journal of Food, Agriculture, Nutrition and Development, Accepted for publication.

Stigter, C. J. and Ofori, E. (2013c). What Climate Change Means for African Farmers. A Triptych Review. Middle Panel. Introductional Matters and Consequences of Global Warming for African Farmers. African Journal of Food, Agriculture, Nutrition and Development, Accepted for publication.

Tubiello, F., Schmidhuber, J., Howden, M., Neofotis, P.G., Park, S., Fernandes, E. and Thapa, D. (2008). Climate change response strategies for agriculture: Challenges and opportunities for the 21st Century. The World Bank Agriculture and Rural Development Discussion Paper 42.

Unganai, L.S. (1996). Historic and future climate change in Zimbabwe. Climate Research, 6: 137-145.

Yanda, P.Z. (2010). Climate change impacts, vulnerability and adaptation in Southern Africa. In P. Kotecha (Ed.), Climate Change, Adaptation and Higher Education: Securing Our Future. Southern African Regional Universities Association Leadership Dialogue Series, 2(4). 